DEFENDING THE CONQUEST 


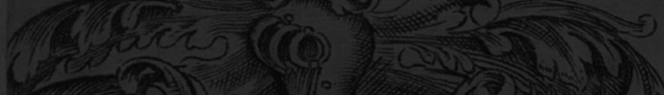

(26, nמ

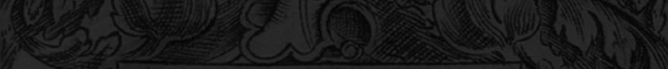

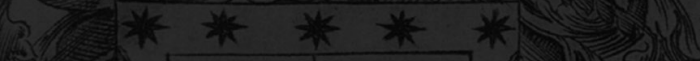

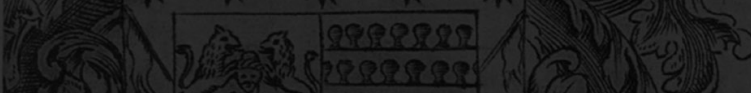

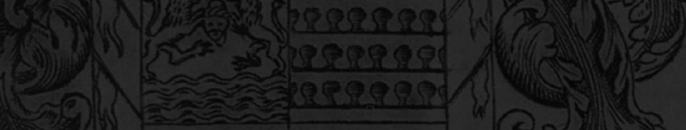

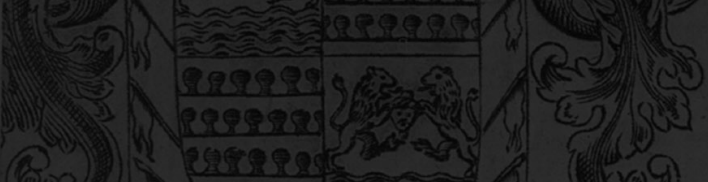

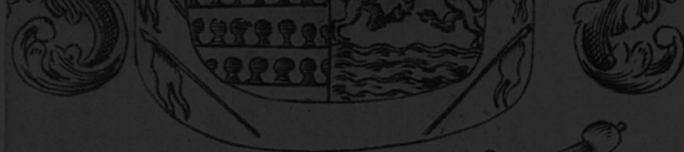

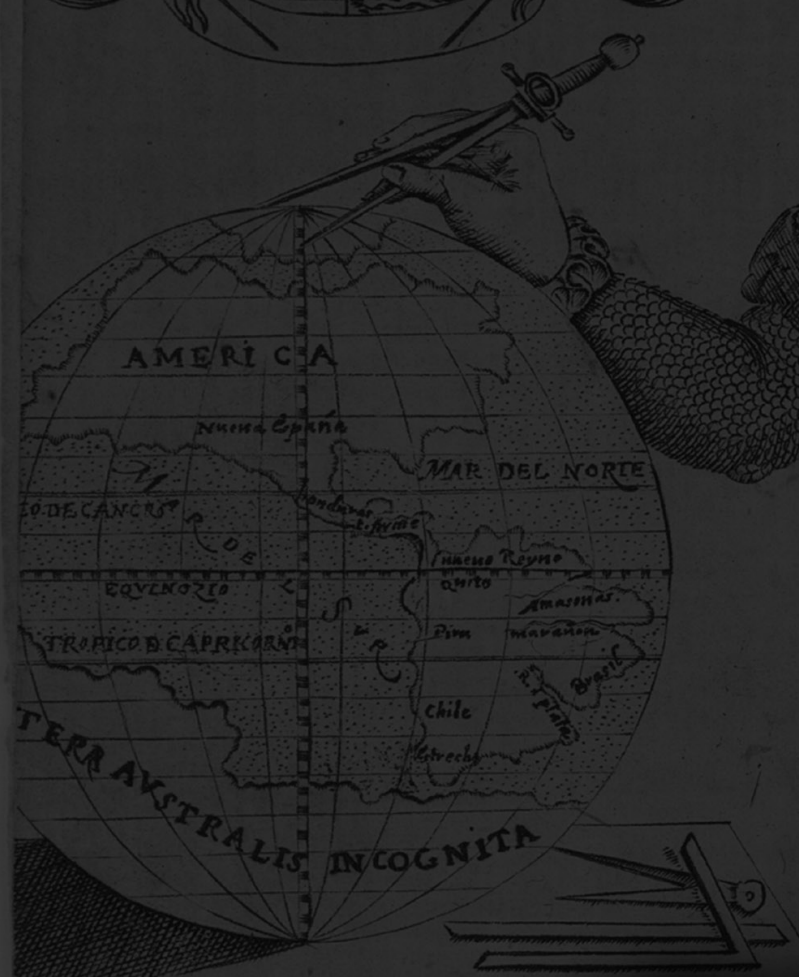




\section{DEFENDING THE CONQUEST}

Bernardo de Vargas Machuca's

Defense and Discourse of the Western Conquests

\section{Edited by Kris Lane}

Translated by Timothy F. Johnson

The Pennsylvania State University Press

University Park, Pennsylvania 
Library of Congress Cataloging-in-Publication Data Vargas Machuca, Bernardo de, 1557-1622.

[Milicia y descripción de las Indias. English]

Defending the conquest : Bernardo de Vargas

Machuca's Defense and discourse of the western conquests / edited by Kris Lane ; translated by Timothy F. Johnson.

p. cm.-(Latin American originals ; 4) Includes bibliographical references and index. Summary: "An English translation and critical edition of a refutation, written about 1603 by the soldier Bernardo de Vargas Machuca, of Bartolome de las Casas's famous Brief Account of the Destruction of the Indies (1558)"-Provided by publisher. ISBN 978-0-271-02937-5 (pbk. : alk. paper)

1. America-Early works to 1600 .

2. Indians of the West Indies-Early works to 1800 .

3. Indians of South America-Early works to 1800.

4. Military art and science-America-Early works to 1800 .

5. America-Discovery and exploration-SpanishEarly works to 1800.

I. Lane, Kris E., 1967- .

II. Johnson, Timothy F.

III. Title.

E141.V3132010

$970.01^{\prime} 6-\mathrm{dc} 22$

2010024251

Copyright (C) 2010

The Pennsylvania State University

All rights reserved

Printed in the United States of America

Published by The Pennsylvania State University Press, University Park, PA 16802-1003

It is the policy of The Pennsylvania State University Press to use acid-free paper. Publications on uncoated stock satisfy the minimum requirements of American National Standard for Information SciencesPermanence of Paper for Printed Library Material, ANSI Z39.48-1992. 